\title{
The apolipoprotein $\mathbf{B}^{3304-3317}$ peptide as an inhibitor of the lipoprotein (a): apolipoprotein B-containing lipoprotein interaction
}

\author{
Vuong N. TRIEU, ${ }^{*}$ Urban OLSSON $\dagger$ and Walter J. MCCONATHY $\ddagger$ \\ *Departments of Medicine and Biochemistry, University of North Texas Health Science Center at Fort Worth, Fort Worth, TX 76107, U.S.A. and \\ †Wallenberg Laboratory, Göteborgs University, Göteborg, Sweden
}

Lipoprotein (a) $[\mathrm{Lp}(\mathrm{a})]$ is a risk factor for coronary artery disease. It is characterized by apolipoprotein (a) [apo(a)] disulphide linked to apolipoprotein B (apoB), by $\mathrm{Cys}^{4057}$ of apo(a) and possibly $\mathrm{Cys}^{3734}$ of apoB. We call this the covalent apo(a): apoB-Lp interaction, to distinguish it from the noncovalent $L p(a)$ :apoB-Lp interaction, mediated by the prolinebinding kringle-4-like domain(s) of $\mathrm{Lp}(\mathrm{a})$. The $\mathrm{Lp}(\mathrm{a})$ : apoB-Lp interaction was inhibited by an apoB peptide spanning residues 3304-3317. This peptide was found by a computerized search for sites on apoB similar to the plasminogen's kringle-4-binding site of $\alpha_{2}$-antiplasmin. It probably constitutes part of the $\mathrm{Lp}(\mathrm{a})$ - binding site on apoB because: (1) it corresponds to the $\alpha_{2^{-}}$ antiplasmin minimum binding domain for plasminogen's kringle$4 ;(2)$ the competitive nature of inhibition $\left[K_{\mathrm{I}}=(1.5 \pm 0.7) \times 10^{-4}\right.$ $M, n=5$ ] suggested that it and apoB-Lp bound to $L p(a)$ by the same mechanism at the same site; and (3) it specifically bound $\mathrm{Lp}(\mathrm{a})$ and not apoB-Lp, and the bound $\mathrm{Lp}(\mathrm{a})$ was dissociated by inhibitors of the $\mathrm{Lp}(\mathrm{a})$ :apoB-Lp interaction, 6-aminohexanoic acid and L-proline. Inhibition was independent of its proline residue, suggesting that proline in the context of a peptide is not a ligand for the kringle(s) which mediated the binding of $L p(a)$ to apoB-Lp.

\section{INTRODUCTION}

Lipoprotein (a) $[\mathrm{Lp}(\mathrm{a})]$ is a risk factor for coronary artery disease [1-3]. It is a low-density lipoprotein (LDL) particle with a distinguishing glycoprotein, apolipoprotein (a) [apo(a)], covalently linked to apolipoprotein $B$ (apoB) by a disulphide bond [4]. Apo(a) is highly homologous to plasminogen and its gene possibly arose by duplication of the plasminogen gene [5]. It has many repeats of kringle-4-like domains, one kringle-5-like domain, and a domain analogous to the protease domain of plasminogen but lacking the activation site [5]. Lp(a) assembly is mediated by $\mathrm{Cys}^{4057}$ of apo(a)'s kringle-36 and possibly Cys ${ }^{3734}$ of apoB [6-8]. We call this the covalent apo(a):apoB-Lp interaction, to distinguish it from the non-covalent $L p(a)$ :apoB-Lp interaction which is the topic of this paper. ApoB-Lp is defined as apoB-containing lipoprotein, exclusive of $\mathrm{Lp}(\mathrm{a})$.

The $\mathrm{Lp}(\mathrm{a})$ : apoB-Lp interaction was initially demonstrated by affinity chromatography, affinity electrophoresis and ligand blotting [9]. When $\mathrm{Lp}(\mathrm{a})$ and $\mathrm{LDL}$ are mixed together, they form an Lp(a): LDL complex which has an intermediate mobility between $\mathrm{Lp}(\mathrm{a})$ and $\mathrm{LDL}$ on agarose gel electrophoresis [9]. $\mathrm{Lp}(\mathrm{a})$, immobilized on nitrocellulose membrane or coupled to Sepharose-6B, binds apoB-Lp [9]. The nitrocellulose membrane system was exploited to quantify the $L p(a)$ :apoB-Lp interaction [10]. The interaction exhibits a binding constant of $2 \times 10^{-8} \mathrm{M}$ and a stoichiometry of two apoB-Lp/one $\mathrm{Lp}$ (a) [10].

The kringle-4-like domain(s) of $L p(a)$ is responsible for the binding of $\mathrm{Lp}(\mathrm{a})$ to apoB-Lp as a synthetic kringle peptide inhibits the binding of apoB-Lp to $\mathrm{Lp}(\mathrm{a})\left(K_{\mathrm{I}}=1.9 \times 10^{-4} \mathrm{M}\right)$ [11]. In comparison with plasminogen kringle-4, the aspartic acid residue critical for lysine binding is replaced by valine in most of Lp(a)'s kringle-4-like domains, conferring affinity to L-proline rather than L-lysine [11]. An analogue of lysine, 6-aminohexanoic acid, can adopt a conformation similar to that of $\mathrm{L}$-proline and can also inhibit the binding of apoB-Lp to $\mathrm{Lp}(\mathrm{a})$ [11].

The $L p(a)$ :apoB-Lp interaction has also been observed in other systems. Immunoprecipitation by anti-apo(a) brought down both $\mathrm{Lp}(\mathrm{a})$ and apoB-Lp non-covalently associated with $\mathrm{Lp}$ (a) [12]. The accumulation of $\mathrm{Lp}(\mathrm{a})$, in the triacylglycerol-rich apoB-Lp fraction of hypertriacylglycerolaemic patients, is mimicked by the addition of purified $\mathrm{Lp}(\mathrm{a})$ to the affected plasma due to the binding of $L p(a)$ to the triacylglycerol-rich apoB-Lp $[10,13,14]$. Lp(a), bound or immobilized on LDL-receptornegative fibroblasts, mediates the binding of additional apoB$\mathrm{Lp}$; the effect is inhibited by L-proline [15]. Similarly, $L p(a)$, bound or immobilized on HepG2 cells, causes a greater than 2fold increase in LDL binding [16].

In this paper, we report our studies of an apoB peptide which inhibits the $L p(a)$ :apoB-Lp interaction. This peptide was found during a computerized search for an apoB equivalent to the $\alpha_{2}-$ antiplasmin-binding domain for plasminogen's kringle-4. The possibility that this peptide constitutes the Lp(a)-binding site on apoB is suggested.

\section{MATERIALS AND METHODS}

\section{Materials}

BSA (essentially fatty acid- and globulin-free), peroxidase substrate, antibodies to sheep IgG, 6-aminohexanoic acid, D-proline and L-proline were purchased from Sigma Chemical Company, St. Louis, MO, U.S.A.; Tween 20 was from J. T. Baker Chemical Company, Phillipsburg, NJ, U.S.A.; prestained molecular-mass standards were from Gibco-BRL, Gaithersburg, MD, U.S.A.; streptavidin-biotinylated peroxidase complex from Amersham Corporation, Arlington Heights, IL, U.S.A.; and nitrocellulose

Abbreviations used: $L p(a)$, lipoprotein (a); apo(a), apolipoprotein (a); apoB, apolipoprotein B; apoB-Lp, apoB-containing lipoprotein exclusive of Lp(a); LDL, low-density lipoprotein $(\rho=1.006-1.063 \mathrm{~g} / \mathrm{ml}) ; L_{2}$, subclass of low-density lipoprotein $(\rho=1.030-1.063 \mathrm{~g} / \mathrm{ml}) ; \mathrm{HDL}$, subclass of highdensity lipoprotein $(\rho=1.063-1.12 \mathrm{~g} / \mathrm{ml})$; VLDL, very-low-density lipoprotein $(\rho<1.006)$; NaSCN, sodium thiocyanate.

$\ddagger$ To whom correspondence and reprint requests should be addressed. 
sheets from BioTrace NT, Gelman Sciences, Ann Arbor, MI, U.S.A. All other chemicals were of reagent grade.

\section{Bestfit search}

Bestfits were found using the local homology algorithm of Smith and Waterman [17] with gap weight of 3.0 and length weight of 0.10 . The apoB sequence was broken down into eight 500 -aminoacid blocks for the search as the GCG program from the Wisconsin Genetic Group is not capable of handling longer sequences effectively.

\section{Lipoprotein Isolation}

Human plasma samples obtained from a local blood bank were collected by plasmapheresis from healthy subjects. To prevent degradation by proteolytic enzymes, the plasma was adjusted with PPACK, leupeptin, $\mathrm{NaN}_{3}$, and phenylmethanesulphonyl fluoride to final concentrations of $1 \mu \mathrm{M}, 40 \mu \mathrm{g} / \mathrm{ml}, 0.1 \%$ and $0.5 \mu \mathrm{M}$, respectively [9]. $\mathrm{LDL}_{2}(\rho=1.030-1.063 \mathrm{~g} / \mathrm{ml})$ and $\mathrm{Lp}(\mathrm{a})$ from high-density lipoprotein (HDL) $)_{2}(\rho=1.063-1.12 \mathrm{~g} / \mathrm{ml})$ were isolated by sequential ultracentrifugation and column chromatography as previously described [9]. Homogeneity of Lp(a) was assessed by non-denaturing gradient gel electrophoresis (GGE) combined with immunoblotting for $\operatorname{Lp}(a)$ and LpB.

Recombinant apo(a) containing 17 kringle-4-like domains plus the kringle-5 and protease domains purified by lysineSepharose chromatography from the conditioned media of transfected human 293 cells [12] was obtained from Dr. Richard Lawn at Stanford University, Palo Alto, CA, U.S.A.

\section{Peptide synthesis}

Synthetic peptides were synthesized on an Applied Biosystem synthesizer (model 430A), purified by h.p.l.c., and characterized by amino acid analysis as described [18] at the Molecular Biology Resource Facility, Oklahoma University Health Sciences Center or in the Wallenberg Laboratory using Milligen peptide synthesizers (Model 9050) according to Sheppard [19], University of Göteborg, Göteborg, Sweden. All synthetic peptides exhibited a single peak on h.p.l.c. and the predicted amino acid composition. The di- and tri-peptides were obtained from Bachem Bioscience Inc., King of Prussia, PA, U.S.A.

\section{Peptide-Sepharose column chromatography}

Synthetic apoB ${ }^{3304-3317}$ peptide $(300 \mathrm{mg})$ was suspended in $50 \mathrm{ml}$ of $0.2 \mathrm{M}$ borate buffer, $\mathrm{pH} 8.5$, and allowed to react with $7 \mathrm{~g}$ of CNBr-activated Sepharose 4B (Pharmacia, Sweden) according to the manufacturer's instructions. By protein determination, $96 \%$ of the peptide was attached to the column. The final bed volume of $40 \mathrm{ml}$ yielded a minimum covalently attached peptide concentration of $4.5 \times 10^{-3} \mathrm{M}$. The peptide column was poured as previously described for immunosorbers [20]. Three $L p(a)-$ positive and three $L p(a)$-negative plasma samples were passed separately over the column after it was equilibrated in $0.05 \mathrm{M}$ Tris/HCl, $\mathrm{pH} 7.5,0.15 \mathrm{M} \mathrm{NaCl}, 0.02 \%$ EDTA and the unretained fraction eluted in the same buffer. The retained proteins were dissociated from the column with $0.1 \mathrm{M}$ 6-aminohexanoic acid or $0.1 \mathrm{M}$ L-proline, followed by $3 \mathrm{M} \mathrm{NaSCN}$ as previously described. The elution pattern was very similar to the pattern from immunosorbers [20]; and each retained fraction was collected and concentrated by dialysis against PEG-18000.
Plasma from random normolipidaemic individuals were classified as $L p(a)$-positive or $L p(a)$-negative by double diffusion analysis using polyclonal anti- $L p(a)$. We have shown previously that this yielded a detection level for $\mathrm{Lp}(\mathrm{a})$-positive plasma of $>9 \mathrm{mg} / \mathrm{dl}$ and $<9 \mathrm{mg} / \mathrm{dl}$ for Lp(a)-negative plasma [21]. The plasma apoB concentration is $96 \pm 24 \mathrm{mg} / \mathrm{dl}$ and plasma $\mathrm{Lp}(\mathrm{a})$ concentration is $18.6 \pm 17.9 \mathrm{mg} / \mathrm{dl}$ [22]. The $\mathrm{Lp}(\mathrm{a})$ and LDL mixture had $34 \mathrm{mg} / \mathrm{dl}$ of $\mathrm{Lp}(\mathrm{a})$ and $800 \mathrm{mg} / \mathrm{dl}$ of LDL. To avoid exceeding the binding capacity of the column, we only used $2 \mathrm{ml}$ of plasma and only $1 \mathrm{ml}$ of the mixture.

\section{Electrophoretic analyses}

SDS/gradient polyacrylamide gel electrophoresis (SDS/PAGE; $2.5-10 \%$ ), non-denaturing polyacrylamide gradient gel electrophoresis (GGE; $1.5-15 \%$ ), and immunoblotting were performed as previously described [11]. In some experiments, alkaline phosphatase-conjugated antibody was used and blots visualized using the phosphatase substrate from Kirkegaard and Perry Laboratories Inc., Gaithersburg, MD, U.S.A.

\section{Llgand dot blotting}

Ligand dot blotting was performed as previously described [10] using Bio-Trace nitrocellulose membrane (Gelman Sciences, Ann Arbor, MI, U.S.A.), 3,3-diaminobenzidine tetrahydrochloride tablets (Ken En Tec, Copenhagen, Denmark) as visualizing agent, and a dot blot apparatus (S \& S, Keene, NH, U.S.A.). In some experiments, the intensity was determined using the Optimas system from BioScan Inc., Edmonds, WA, U.S.A. $\mathrm{LDL}_{2}$ was biotinylated by reaction of a $1 \mathrm{mg} / \mathrm{ml}$ solution of purified lipoproteins in $0.2 \mathrm{M}$ borate buffer, $\mathrm{pH} 8.5$, with $60 \mu \mathrm{l} / \mathrm{ml}$ of freshly made Biotin-X-NHS (Boehringer Mannheim), $1.2 \mathrm{mg} / \mathrm{ml}$ in dimethyl sulphoxide as described [9].

\section{Other methods}

Double diffusion was performed using monospecific antisera as described previously using $1 \%$ agar in Veronal buffer [11]. Protein determination was performed using the Bio-Rad dye reagent (Richmond, CA, U.S.A.).

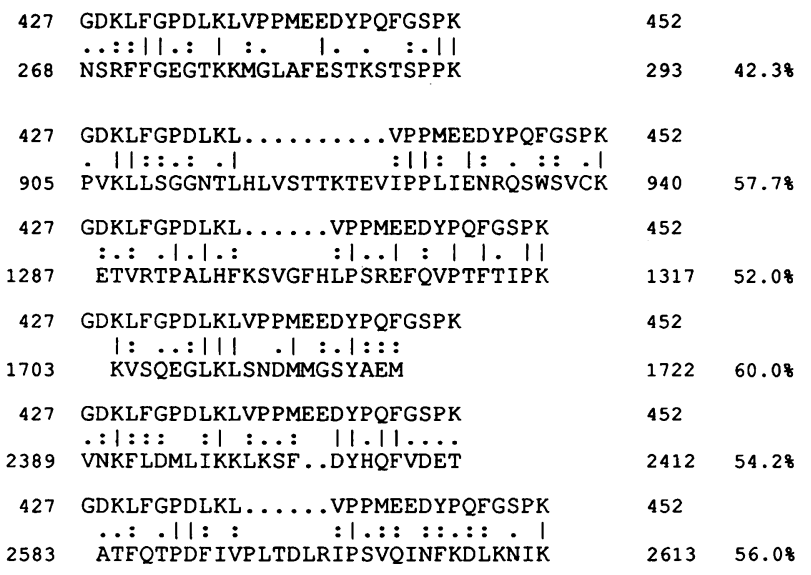

\section{Figure 1 Polypeptides of apoB found to be similar to the T-11 peptide of $\alpha_{2}$-antiplasmin}

The bars, two dots, and one dot indicate identical, similar, and weakly similar residues. The percentage similarity of each site is indicated on the right-hand column. For each pair, the $\mathrm{T}-11$ sequence is listed on top and the apoB sequence is listed on bottom. 
SITE 1

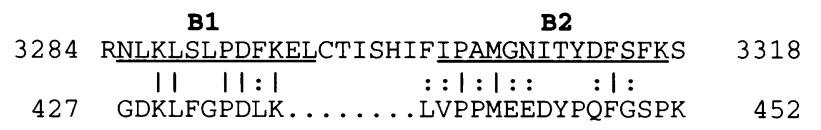

SITE 2
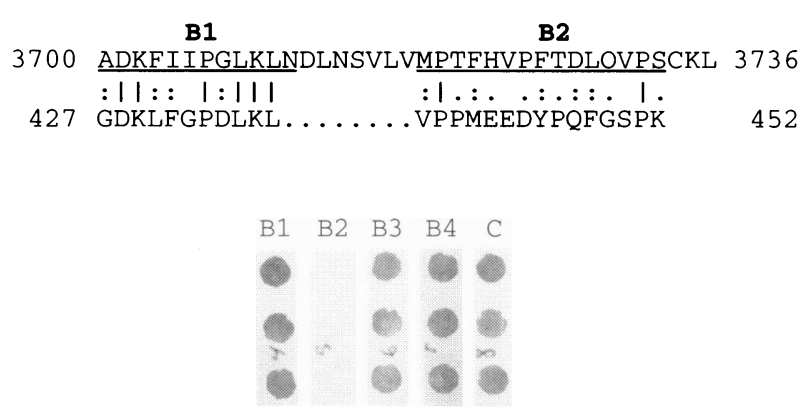

\section{Figure 2 Putative Lp(a)-binding site(s) on apoB}

The two sites exhibiting the greatest similarity to the T-11 peptide are shown. The bars, two dots, and one dots indicate identical, similar, and weakly similar residues. The underlined residues indicate the four peptides tested in the lower panel for inhibition of binding. The lower panel shows $150 \mathrm{ng}$ of $\mathrm{Lp}(\mathrm{a})$ immobilized per dot and reacted with $1.2 \times 10^{-8} \mathrm{M}$ biotinylated $\mathrm{LDL}_{2}$ in the presence of $8.5 \times 10^{-4} \mathrm{M}$ inhibitors [B1, B2 $\left(\mathrm{apoB}^{3304-3317}\right), \mathrm{B} 3$, and $\left.\mathrm{B} 4\right]$. C indicates the control with no inhibitor added.

\section{RESULTS}

\section{Inhibition of $L p(a): a p o B-L p$ interaction by apoB $B^{3304-3317}$ peptide}

The T-11 tryptic peptide ( $\mathrm{G}^{427}$ DKLFGPDLKLVPPMEEDYPQFGSPK ${ }^{452}$ ) of $\alpha_{2}$-antiplasmin has an affinity for plasminogen's kringle- 4 with a $K_{\mathrm{D}}$ of $0.7-29 \mu \mathrm{M}$; the right half of which is the minimum binding site and has a $K_{\mathrm{D}}$ of $250 \mu \mathrm{M}$ [23]. The human apoB amino acid sequence was searched for sequences similar to the T-11 sequence. The results are shown in Figures 1 and 2. The two sites shown in Figure 2 were chosen for further analyses, since they have the highest similarity to the T-11 sequence. Site 1 (residues 3284-3318) and site 2 (residues 3700-3733) exhibit $76 \%$ and $65 \%$ sequence similarity to the $\mathrm{T}-11$ sequence respectively (Figure 2). Alignment at site 1 and site 2 forced a gap which breaks the $\mathrm{T}-11$ sequence into half, the right half corresponds to its minimum binding site.

Synthetic peptides spanning residues 3285-3296 (B1), 3304 3317 (B2), 3700-3711 (B3), and 3719-3733 (B4), were tested for inhibition of the $\mathrm{Lp}(\mathrm{a})$ : apoB-Lp interaction. As shown in Figure 2, peptide $\mathrm{B} 2$ (apoB $^{3304-3317}$ ) completely inhibited the binding of biotinylated $\mathrm{LDL}_{2}$ to immobilized $\mathrm{Lp}(\mathrm{a})$. The apoB ${ }^{3304-3317}$ peptide also inhibited the binding of $\mathrm{LDL}_{2}$ to recombinant apo(a) (data not shown). These data suggested that site 1 is the $\mathbf{L p}$ (a)-binding site on apoB. This interpretation is consistent with the competitive nature of inhibition by the apo $\mathrm{B}^{3304-3317}$ peptide. In the presence of increasing amounts of apo $B^{3304-3317}$ peptide, the apparent $K_{\mathrm{D}}$ decreased while maximum binding $\left(B_{\text {max }}\right)$ was not affected (Figure 3). The $K_{\mathrm{I}}$ was determined to be $(1.5 \pm 0.7) \times 10^{-4} \mathrm{M}$ of apoB $^{3304-3317}$ peptide $(n=5) . K_{\mathrm{I}}$ was determined graphically by plotting the apparent $K_{\mathrm{D}}$ values versus the inhibitor concentrations; the $x$-axis intercept is equal to $-K_{\mathrm{I}}$ (Figure 3) $[10,11]$.

\section{Binding of $L p(a)$ to the apoB $B^{3304-3317}$ peptide}

When Lp(a)-positive plasma samples were passed over the
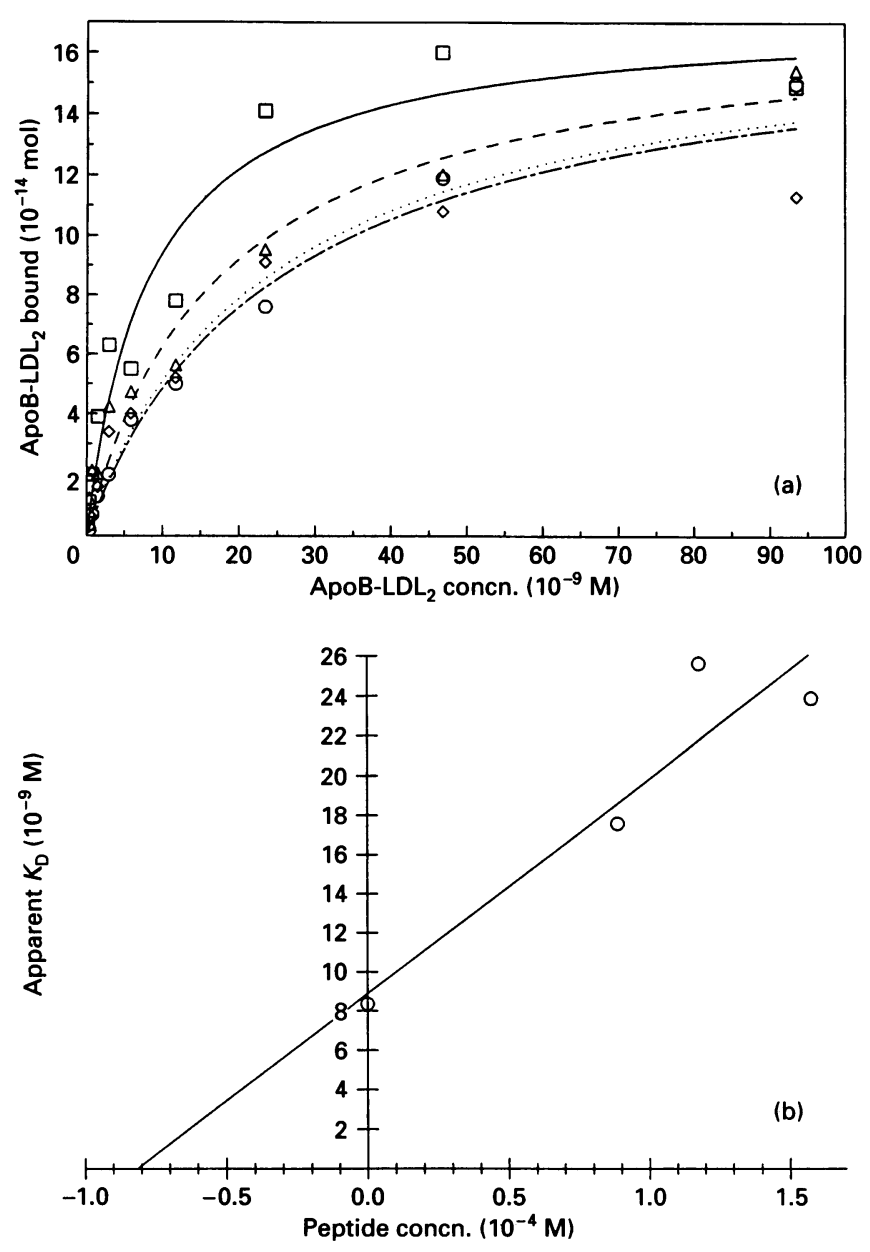

Figure 3 Competitive inhibition of apoB-Lp binding to Lp(a) by apoB $B^{3304-3317}$

(a) The binding isotherm was determined in the presence of apo $\mathrm{B}^{3304-3317}$ peptide at the concentration of $0\left(\square\right.$, solid line), $0.89 \times 10^{-4} \mathrm{M}\left(\triangle\right.$, dashed line), $1.18 \times 10^{-4} \mathrm{M}(\diamond$, dashed line), and $1.58 \times 10^{-4} \mathrm{M}(\mathrm{O}$, dotted line). The amount of $L p(a)$ used per dot was $150 \mathrm{ng}$. The curves were fitted to the data using the equation apoB-LDL $L_{2}$ bound $=$ $\left(B_{\text {max }} \times\left[L D L_{2}\right]\right) /\left(K_{0}+\left[L_{2} L_{2}\right]\right)$ with the GraphPad computer program. (b) The apparent $K_{D}$ values were plotted versus the concentration of apo $\mathrm{B}^{3304-3317}$ peptide used. The $x$-axis intercept equals $-K_{1}$.

apoB $B^{3304-3317}$-Sepharose column, $\mathrm{Lp}(\mathrm{a})$ was bound and was eluted with $0.1 \mathrm{M}$ 6-aminohexanoic acid (Figure 4). This was the case with or without prior passage over L-lysine-Sepharose to remove proteins with affinity for amino acids [especially L-lysine which also has an affinity for $\mathrm{Lp}(\mathrm{a})$ ]. The double immunodiffusion reactions to apo(a) and apoB of all 6-aminohexanoic acid fractions exhibited a line of identity, indicating that apo(a) and apoB reside on the same particle, i.e. $L p(a)$ (Figures $4 b$ and $4 c$ ). And upon immunoblotting, Lp(a)-positive plasma exhibited two apo $B$ reactivities corresponding to $a p o B$ and $a p o B$ linked to apo(a) (Figure 5, lane 1); while the 6-aminohexanoic acid eluate exhibited primarily one reactivity corresponding to apoB linked to apo(a) (Figure 5, lanes 3 and 4). This showed that only $L p(a)$, and not apoB-Lp, was bound by the column. Little or no $L p(a)$ remained after 6-aminohexanoic acid elution, as no $L p(a)$ was detected with the subsequent $3 \mathrm{M} \mathrm{NaSCN}$ wash (Figure 5, lane 2).

The binding of $\mathrm{Lp}(\mathrm{a})$ to the column was specific because of four facts. First, $\mathrm{Lp}(\mathrm{a})$ did not bind to a column constructed 
(a)

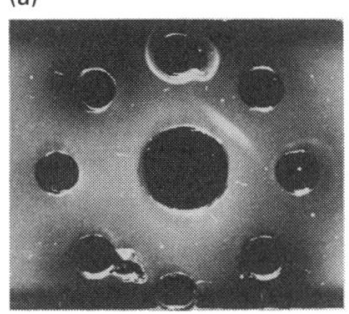

(b)

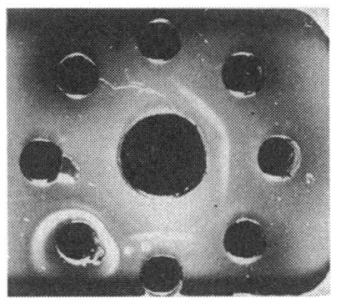

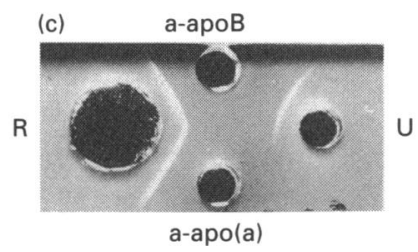

Figure 4 Double immunodiffusion analyses of proteins bound to apoB ${ }^{3304-3317-S e p h a r o s e ~}$

Lp(a)-positive plasma samples were passed over the column and the bound material eluted with $0.1 \mathrm{M}$ 6-aminohexanoic acid. The eluate, centre wells, was reacted with the following antisera in clockwise order from the top: (a) apoA-I, apo(a), apoA-II, apoA-IV, apoC-III, apoC-II, apoC$\mathrm{I}$, and apoD; (b) apoE, apo(a), apoB, plasminogen, fibrinogen, fibronectin, cholesterol ester transfer protein, and apoH. (c) A mixture containing only LDL and $L p(a)$ was passed over the apo $B^{3304-3317}$-Sepharose column and eluted with $0.1 \mathrm{M}$ 6-aminohexanoic acid. The unretained material $(U)$ and the retained material $(R)$ were reacted against anti-apo(a) and anti-apoB.

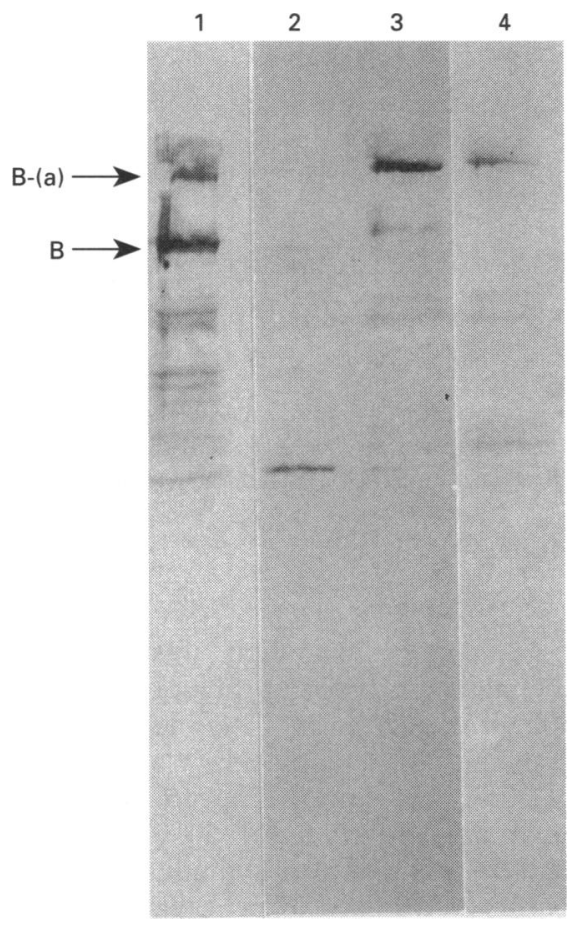

Figure 5 Immunoblot analysis of apoB ${ }^{3304}-3317$-Sepharose column fractions

Protein $(1 \mu \mathrm{g})$ from the 6-aminohexanoic acid eluate (lanes 3 and 4 ), the corresponding $3 \mathrm{M}$ NaSCN eluate (lane 2), and $1 \mu \mathrm{l}$ of the starting plasma (lane 1) were separated on a 2.5-10\% SDS/PAGE. The separated proteins were immunoblotted with anti-apoB (lanes 1-3) and antiapo(a) (lane 4). The arrows indicate the location of apoB and apoB linked to apo(a).

using an unrelated peptide (Asp-Pro-Gly-Val-Arg-Trp-Glu-TyrCys-Asn-Leu-Thr-Glu) (results not shown). Secondly, L-proline, which is less effective than 6-aminohexanoic acid in inhibiting the

\section{Table 1 Inhlbition of binding by various peptides}

B2 and its variants were used at $5 \times 10^{-4} \mathrm{M}$. The dipeptides and tripeptide were used at $0.1 \mathrm{M}$. Other experimental details are as in Figure 6 . The results are given as means \pm S.D. $(n=3)$.

\begin{tabular}{ll}
\hline Inhibitors & Inhibition (\%) \\
\hline B2 & $99.7 \pm 0.6$ \\
B2 (Lys $\rightarrow$ Gly) & $73.3 \pm 19.8$ \\
B2 (Pro $\rightarrow$ Gly) & $91.5 \pm 9.6$ \\
Gly-Tyr & $13.8 \pm 4.4$ \\
Gly-Pro-Ala & $13.8 \pm 4.4$ \\
Gly-Pro & $53.7 \pm 5.5$
\end{tabular}

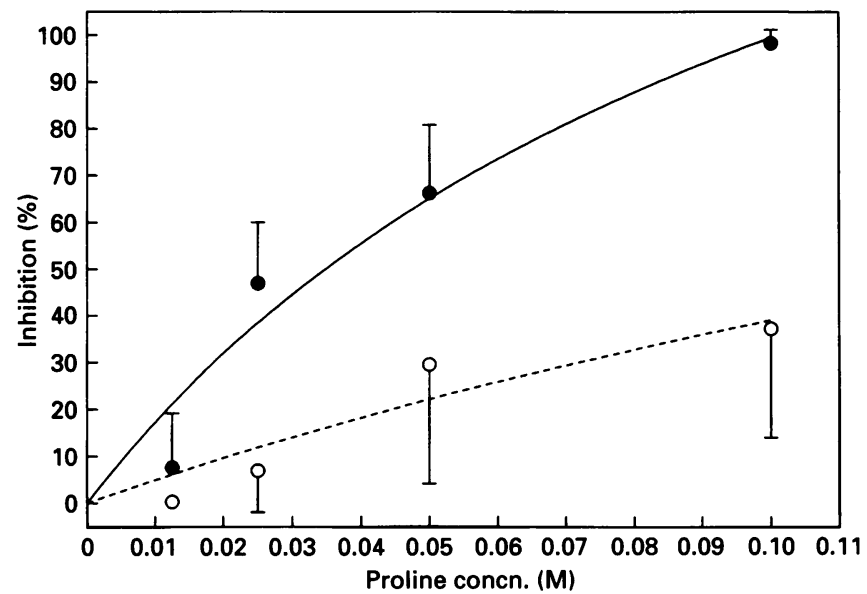

Figure 6 Inhibition of Lp(a):apoB-Lp interaction by L-proline and D-proline

$\mathrm{Lp}(\mathrm{a})(158 \mathrm{ng} / \mathrm{dot})$ was immobilized and reacted with $2.34 \times 10^{-8} \mathrm{M}$ biotinylated $\mathrm{LDL}_{2}$ in the presence of L-proline $(O)$ or $D$-proline $(O)$. The percentage inhibition was calculated as the ratio of $\mathrm{LDL}_{2}$ bound in the presence of the inhibitor and $\mathrm{LDL}_{2}$ bound in the absence of the inhibitor, multiplied by 100 . The data were compiled from three separate experiments.

$\mathrm{Lp}(\mathrm{a})$ :apoB-Lp interaction, was also less effective in eluting $\mathrm{Lp}$ (a) from the apo $\mathrm{B}^{3304-3317}$ column (results not shown). Thirdly, no other apolipoproteins, including apoB-Lp, were bound to the column, as determined by double immunodiffusion analyses (Figures $4 \mathrm{a}$ and $4 \mathrm{~b}$ ) or immunoblotting (Figure 5). Fourthly, binding was independent of other plasma proteins as only $L p(a)$ was bound when a mixture of purified LDL and $\mathrm{Lp}(\mathrm{a})$ was passed over the column (Figure 4c).

\section{The proline of apoB ${ }^{3304-3317}$ is not essential}

Since lysine is probably blocked during coupling of the peptide to Sepharose, the effective binding of $L p(a)$ to the immobilized peptide suggested that lysine was not essential for binding. Consequently, replacement of lysine by glycine did not significantly reduce its inhibitory activity in comparison with the control peptide $(P=0.083)$ (Table 1$)$. Surprisingly, replacement of proline by glycine also did not reduce its inhibitory activity $(P$ $=0.216$; Table 1). This suggested that proline, in the context of a peptide, is not a ligand for the kringle(s) which mediates the binding of $\mathrm{Lp}(\mathrm{a})$ to apoB-Lp. Consequently, the tripeptide GlyPro-Ala was ineffective as an inhibitor; and the dipeptide GlyPro was inhibitory only at a concentration of $0.1 \mathrm{M}(P<0.001$, in comparison with the control peptide, Gly-Tyr) (Table 1). 
However, like lysine and plasminogen [24], inhibition by free proline was characterized by stereospecificity; L-proline was more effective than D-proline (Figure 6). Furthermore, the $K_{\mathrm{I}}$ of $\mathrm{L}$-proline for $\mathrm{Lp}$ (a) (Figure 6) is equivalent to the $K_{\mathrm{I}}$ of L-lysine for plasminogen [25] (30 mM versus $25-27 \mathrm{mM})$. Thus free Lproline is probably a ligand for the kringle(s) which mediates the binding of $\mathrm{Lp}(\mathrm{a})$ to apoB-Lp.

\section{DISCUSSION}

We have shown that the binding of $\mathrm{Lp}(\mathrm{a})$ to apoB-Lp is inhibited by an apoB peptide spanning residues 3304-3317. It is likely that this peptide is part of the $\mathrm{Lp}(\mathrm{a})$-binding site on apoB for three reasons. First, the peptide corresponds to the $\alpha_{2}$-antiplasmin minimum binding domain for plasminogen's kringle- 4 which is highly homologous to Lp(a)'s kringle-4-like domains. Secondly, the competitive nature of inhibition suggested that the peptide and apoB-Lp bound to $\mathrm{Lp}(\mathrm{a})$ by the same mechanism at the same site(s). Thirdly, the peptide specifically bound $L p(a)$ and not apoB-Lp; and the bound $\mathrm{Lp}(\mathrm{a})$ was dissociated by inhibitors of the $L p(a)$ :apoB-Lp interaction, i.e. 6-aminohexanoic acid and Lproline.

The $\mathrm{Lp}(\mathrm{a})$ : apoB-Lp interaction is both hydrophobic and ionic; however, the hydrophobic forces predominated because the interaction is demonstrable at a high salt concentration $(>2 \mathrm{M}$ $\mathrm{NaCl}$ ), while no interaction is demonstrable at low salt concentration $(<0.08 \mathrm{M} \mathrm{NaCl})$. Therefore, the binding site for $\mathrm{Lp}$ (a) was predicted to be an exposed hydrophobic domain on apoB [10]. Site 1 is probably hydrophobic and exposed on the basis of its theoretical hydrophobicity index and antigenicity index. In contrast, site 2 may not be exposed based on its low antigenicity index. Close to site 1 are three glycosylation sites (residues 3309, 3331, and 3384) [26]. Glycosylation should insure the surface exposure of site 1 and might contribute sterically to the binding reaction. In this regard, it has been shown by protease digestion, using 12 different proteases, that there is only one highly exposed region in LDL and very-low-density lipoproteins (VLDL) (residues 3180-3280) [27]. Site 1 is in close proximity to this exposed region and should be available for the binding between apoB-100 of both VLDL and LDL to Lp(a) as shown previously [28]. Therefore, site 1 is probably the $L p(a)-$ binding site on apoB. The fact that site 2 , which corresponds to the apoB domain involved in the covalent apo(a):apoB-Lp interaction, was also detected by the computerized search suggested that this apo(a):apoB-Lp interaction could also be analogous to the plasminogen: $\alpha_{2}$-antiplasmin interaction.

Despite the fact that site 1 was found using the $\alpha_{2}$-antiplasmin minimum binding site for plasminogen kringle-4, we would like to point out that site 1 is similar to, but not the same as, the T11 peptide of $\alpha_{2}$-antiplasmin, as reflected in the low degree of similarity between the two domains. Purified $\alpha_{2}$-antiplasmin was not able to inhibit the binding of LDL to immobilized Lp(a) even when added at a concentration of $0.5 \mathrm{mg} / \mathrm{ml}\left(7.6 \times 10^{-6} \mathrm{M}\right)$. Furthermore, apoB-Lp binding to $\mathrm{Lp}(\mathrm{a})$ is lipid dependent, delipidized apoB refolded according to the method of Kamanna et al. [29] did not bind to $\operatorname{Lp}(\mathrm{a})$ (V. N. Trieu, unpublished work); and $\alpha_{2}$-antiplasmin binding to plasminogen is not lipid dependent.

The apoB $B^{3304-3317}$ column has allowed us to remove $L p(a)$ from the plasma compartment rapidly and efficiently. The minimum peptide concentration of this column is $4.5 \times 10^{-3} \mathrm{M}$ which is 30 times the $K_{\mathrm{I}}$ of the peptide and 5 times the concentration of the peptide which completely inhibited apoB-Lp binding to $L p(a)$ at any apoB-Lp concentrations. Therefore, it is not unexpected that we could remove most of the $L p(a)$ from $2 \mathrm{ml}$ of plasma despite the presence of apoB-Lp in the plasma. This observation offers an opportunity to develop a new and rapid $L p(a)$ assay, i.e. $L p(a)$ from plasma could be immobilized on to a peptide-containing support and its cholesterol determined directly or after dissociation of $\mathrm{Lp}(\mathrm{a})$ from the matrix.

The formation of $L p(a)$ :apoB-Lp complex could be of importance physiologically. It has been shown to result in the enhancement of apoB-Lp binding to LDL-receptor-negative fibroblasts and enhanced uptake of both $L p(a)$ and LDL in LDL-receptor-positive HepG2 cells [15,16]. The piggybacking effect of $\mathrm{Lp}(\mathrm{a})$ could explain why $\mathrm{Lp}(\mathrm{a})$ was catabolized more rapidly in transgenic mice overexpressing $L D L$ receptor although it has little affinity for LDL receptor [30]. As there is also a distinct receptor on macrophages [31,32], the binding of $L p(a)$ to apoB-Lp should result in a similar enhancement of apoB-Lp uptake and therefore foam-cell formation which is the first step in atherosclerosis. Furthermore, as $\mathrm{Lp}$ (a) has an affinity for both the extracellular matrix and $\mathrm{apoB}$, it could enhance the binding of apoB to the vascular wall. Normal cellular responses to the bound LDL could result in the formation of atherosclerotic lesions.

We would like to thank Drs. Sven-Olof Olofsson and Göran Bondjers for their help and E. Mills for technical help. This work was supported by the U.S.A. PHS grant HL-46967 and grants from the Swedish Research Council, No. 7142 and 4531.

\section{REFERENCES}

1 Armstrong, V. W., Cremer, P., Eberle, E., Manke, A., Schulze, F., Wieland, H., Kreuzer, H. and Seidel, D. (1986) Atherosclerosis 62, 249-257

2 Dahlen, G. H., Guyton, J. R., Attar, M., Farmer, J. A., Kautz, J. A. and Gotto, A. M. (1986) Circulation 74, 758-765

3 Durrington, P. N., Ishola, M., Hunt, L., Arrol, S. and Bhatnagar, D. (1988) Lancet I, 1070-1073

4 Fless, G. M., ZumMallen, M. E. and Scanu, A. (1986) J. Biol. Chem. 261, 8712-8718

5 McLean, J. W., Tomlinson, J. E., Kuang, W.-J., Eaton, D. L., Chen, E. Y., Fless, G. M. Scanu, A. M. and Lawn, R. W. (1987) Nature (London) 330, 132-137

6 Koschinsky, M. L., Cote, G. P., Gabel, B. and van der Hoek, Y. Y. (1993) J. Biol. Chem. 268, 19819-19825

7 Brunner, C., Kraft, H.-G., Utermann, G. and Muller, H.-J. (1993) Proc. Natl. Acad. Sci. U.S.A. 90, 11643-11647

8 Guevara, J., Spurlino, J., Jan, A. Y., Yang, C.-Y., Tulinsky, A., Prasdad, V. B. V., Gaubatz, J. W. and Morrisett, J. D. (1993) Biophys. J. 64, 686-700

9 Ye, S.-Q., Trieu, V. N., Stiers, D. L. and McConathy, W. J. (1988) J. Biol. Chem. 263 $6337-6343$

10 Trieu, V. N. and McConathy, W. J. (1990) Biochemistry 29, 5919-5924

11 Trieu, V. N., Zioncheck, T. F., Lawn, R. M. and McConathy, W. J. (1991) J. Biol. Chem. 266, 5480-5485

12 Koschinsky, M. L., Tomlinson, J. E., Zioncheck, T. F., Schwartz, K., Eaton, D. L. and Lawn, R. M. (1991) Biochemistry 30, 5044-5051

13 Sandholzer, C., Feussner, G., Brunzell, J. and Utermann, G. (1992) J. Clin. Invest. 90, 1958-1965

14 Sullivan, D. R., Lam, C. W. K., Jessup, W., Dean, R. T. and Hensley, W. J. (1993) Atherosclerosis 103, 139-147

15 Kostner, G. M. and Grillhofer, H. K. (1991) J. Biol. Chem. 266, 21287-21292

16 Kostner, G. M. (1993) Arteriosclerosis Thromb. 13, 1101-1109

17 Smith, T. F. and Waterman, M. S. (1981) J. Mol. Biol. 147, 195-197

18 McConathy, W. J. and Wang, C.-S. (1989) FEBS Lett. 251, 250-252

19 Sheppard, R. C. (1989) Science Tools 33, 9-16

20 McConathy, W. J., Koren, E., Wieland, H., Campos, E. M., Lee, D. M., Kloer, H. U. and Alaupovic, P. (1985) J. Chromatogr. 342, 47-66

21 McConathy, W. J., Trieu, V. N., Klor, H. U. and Corder, C. N. (1990) Klin Wochenschr. 68 (Suppl. XXII), 117-119

22 McConathy, W. J., Trieu, V. N., Koren, E., Wang, C.-S. and Corder, C. C. (1994) Chem. Phys. Lipids 67/68, 105-113

23 Sugiyama, N., Sosaki, T., Iwamoto, M. and Abiko, Y. (1988) Biochim. Biophys. Acta 952, 1-7

24 Ramesh, V., Petros, A. M., Llinas, M., Tulinsky, A. and Park, C. H. (1987) J. Mol. Biol. 198, 481-498 
25 Castellino, F. J. (1981) Chem. Rev. 81, 431-446

26 Yang, C.-Y., Chen, S.-H., Glanturco, S. H., Bradley, W. A., Sparrow, J. T., Tanimura, M., Li, W.-H., Sparrow, D. A., DeLoof, H., Rosseneu, M., Lee, F.-S., Gu, Z.-W., Gotto, A. M. and Chan, L. (1986) Nature (London) 323, 738-742

27 Chen, C. G., Zhu, S., Hardman, D. A., Schilling, J. W., Lau, K. and Kane, J. P. (1989) J. Biol. Chem. 264, 14369-14375

28 McConathy, W. J. and Trieu, V. N. (1991) Prog. Lipid Res. 30, 195-203
29 Kamanna, V. S., Stiers, D. L. and Lee, D. M. (1990) Biochim. Biophys. Acta 1043, 119-121

30 Hofmann, S. L., Eaton, D. L., Brown, M. S., McConathy, W. J., Goldstein, J. L. and Hammer, R. E. (1990) J. Clin. Invest. 85, 1542-1547

31 Zioncheck, T. F., Powell, L. M., Rice, G. C., Eaton, D. L. and Lawn, R. M. (1991) J. Clin. Invest. 87, 767-771

32 Bottalico, L. A., Keesler, G. A., Fless, G. M. and Tabas, I. (1993) J. Biol. Chem. 268, $8569-8573$

Received 25 July 1994/8 November 1994; accepted 21 November 1994 